\title{
DESIGNING CALORIMETER MADE FROM VARIOUS WASTES
}

\author{
Ida Farida*, Gilang Saeful Akbar, and Riri Aisyah \\ Department of Chemistry Education, Universitas Islam Negeri Sunan Gunung Djati \\ Jl. A.H. Nasution No.105, Cipadung, Cibiru, Bandung 40614, West Java, Indonesia \\ *Correspondence: email: farchemia65@uinsgd.ac.id
}

\begin{abstract}
A research has been conducted which aims to design a waste-based calorimeter as an alternative to measuring heat for chemistry practicum in schools. Research products developed through the steps of design-based research comprising the steps of analysis, design, and development. The resulting product is a waste-based calorimeter equipped with an automatic stirrer. The container to store the reagent solution on the calorimeter is made of Styrofoam, paper, plastic, melamine, PVC and bamboo. Optimization tool was conducted to determine the heat capacity of the calorimeter and the enthalpy of neutralization. The highest accuracy calorimeter value between $78-97 \%$. Bamboo calorimeter has the highest accuracy value (97\%). Styrofoam calorimeter has the lowest accuracy values (78\%). Based on the results of the validation and feasibility test it can be concluded that the product is declared valid and feasible.
\end{abstract}

Keywords: waste-based calorimeter, calorimeter heat capacity, enthalpy change of neutralization

\section{INTRODUCTION}

Chemistry is one branch of science that is very closely related to life so it needs to be learned by students. The concepts in chemistry are very broad, from simple concepts to very complex and abstract concepts [1]. The concept of chemistry is also obtained from experimental activities whose development is obtained through research activities. Therefore, practicum or experimental activities are needed in studying chemistry [2]. Practical activities make it easier for students to understand the concepts being learned [3]. Through practicum, students make direct observations of chemical phenomena [4].

One of the concepts of chemistry that needs to be studied accompanied by practicum is thermochemistry. The concept of thermochemistry is a concept learned in Class $\mathrm{XI}$ in high school. Based on the national curriculum, the basic competencies of thermochemistry include aspects of knowledge that is understanding of various types of reaction enthalpy, Hess's law and the concept of bond energy [5] . The skill aspect developed is the determination of the change in reaction enthalpy by applying Hess's Law based on the enthalpy of formation or bond energy. Determination of the reaction enthalpy based on the results of heat measurement using calorimetry [6].

Generally, the determination of the heat of reaction in the school laboratory using a simple colorimetric insulator is made of 
container. The working principle of a calorimeter is to measure changes in reaction temperature and heat capacity at constant pressure. Data obtained from measurements are used to determine the heat of the reaction by applying the Black Principle, [7].

Simple calorimeters available in school laboratories made of aluminum wrapped in plastic and equipped with a manual stirring rod with a ring-shaped end. Based on preliminary experiments conducted by researchers, it was found that there were problems with accuracy in determining the calorimeter heat capacity. The value of the calorimeter heat capacity produced is always negative. This shows that the calorimeter releases heat. Theoretically, the calorimeter should absorb heat and the value of the resulting heat capacity is positive [8],[9]. Allegedly, this is due to the stirring rotation manually is not constant. In addition, the hand directly touches the ring-shaped stirrer resulting in heat transfer.

Several studies have used a calorimeter made of styrofoam [7], [10], [11], paper [12], and plastics [13]. These studies use automatic magnetic stirrers which produce high measurement accuracy. At school, the use of magnetic stirrers is an obstacle. Not all school laboratories have a magnetic stirrer. The price of magnetic stirrer is quite expensive and can only be used in places that have electricity sources. Thus, the use of magnetic stirrers is less economical and practical. However, replacing the insulator material on the calorimeter using Styrofoam, paper, and plastic can be followed. These materials are easily obtained in everyday life and often become waste that pollutes the environment.

Based on this, the researcher considers it important to innovate a simple calorimeter used in school laboratories. The calorimeter isolator material is replaced with a variety of used materials available in the environment (other than those previously studied) and is equipped with self-made automatic stirrers. The innovation is expected to be developed in schools by teachers and students, thus providing an alternative tool or medium to carry out lab work more interesting and fun [14], [15].

\section{METHODS}

The research product was developed using design-based research (DBR) [16]. This method consists of five stages, namely analysis, design, development, implementtation, and evaluation. However, in this study only three steps were carried out, namely the analysis, design and development stages. [17].

The analysis phase is a theoretical and empirical study to get the results of the needs analysis. At the design stage, product design, tool and material determination and product packaging. At the development stage carried out: product optimization in the laboratory, validation and feasibility test. The product validation test was conducted by three chemists, while the eligibility test was conducted by 12 prospective teacher students. Data collected from the results of the validation test products were processed and analyzed by comparing the value of $r$ count with critical $r$ value set that is equal to 0.3 [18]. The feasibility value $(r$ count) is determined using equation (1). 


$$
r=\frac{x}{N \cdot n}
$$

The feasibility test data were analyzed by changing the frequency of answers from the questionnaire respondents into percentages. The questionnaire obtained from the respondent is given a score and then presented with equation (2):

$$
\%=\frac{\sum n}{N} \times 100 \%
$$

Data obtained from the feasibility test are then interpreted using Table 1.

\begin{tabular}{ccc} 
Table & $\begin{array}{c}\text { 1. } \\
\text { Percentage Value [19] }\end{array}$ & Feasibility \\
\hline No. & Percentage (\%) & Interpretation \\
\hline 1 & $90-100$ & very decent \\
2 & $80-89$ & worthy \\
3 & $70-79$ & pretty decent \\
4 & $60-69$ & not worth it \\
5 & $<60$ & not feasible \\
\hline
\end{tabular}

\section{RESULTS AND DISCUSSION}

The prototype design of the Calorimeter was made to facilitate the process of making products that meet the validity and eligibility criteria. The design is outlined in the form of images that display concrete ideas that are attractive, efficient, and effective according to the usability criteria of the product [20], [21]. The intended product design includes: preparation of selection of insulator material for calorimeter containers, material for automatic stirrers and arrangement of product components. The insulating material for the reactant in the calorimeter must have a low thermal conductivity value.
Such materials cannot transfer heat from the system to the environment or vice versa [22]. Insulator material must be easily obtained in everyday life or utilize waste that can still be recycled. It is intended that products that are created are environmentally friendly and have low prices [23], [24] .

Calorimeters from various simple materials are equipped with automatic stirrers which must have constant and uniform stirring specifications. For this reason, the mixer is connected to an electronic circuit that uses direct current (DC) electricity. The design of the automatic stirrer can be seen in Figure 1.

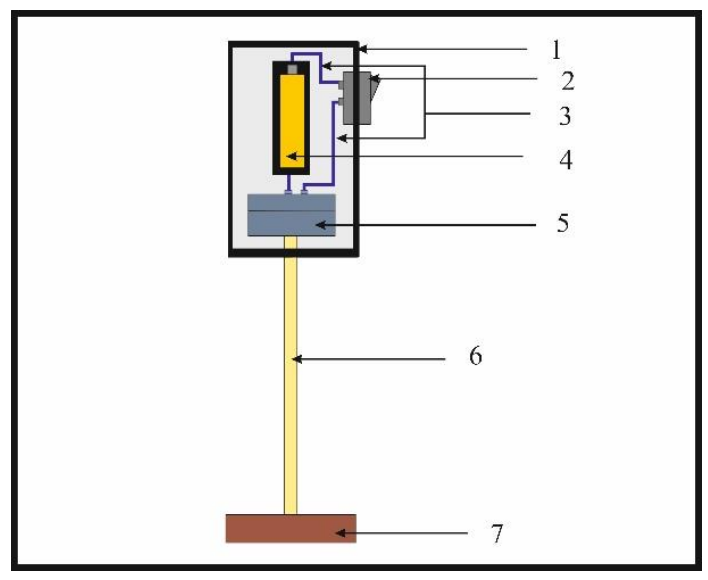

Figure 1. The desain of automatic stirrer

Caption:

1 = black box

2 = Switch

$3=$ Copper wire

$4=$ Battery

$5=$ Dynamo

$6=$ Stirring rod

$7=$ pinwheel of stirring

The desain of the calorimeter made from various wastes can be seen in Figure 2 . Alternative materials used as reagent containers in calorimeters are Styrofoam, paper, plastic, melamine, PVC pipe (Polivynil Chloride), and bamboo. These materials are isolators that inhibit heat transfer from the system to the environment or vice versa [25]. 
The use of insulating material will produce a careful measurement of reaction heat. In this research we want to know which materials can more accurately produce heat measurements. Thus, the next step is to determine the thermal conductivity of each material.

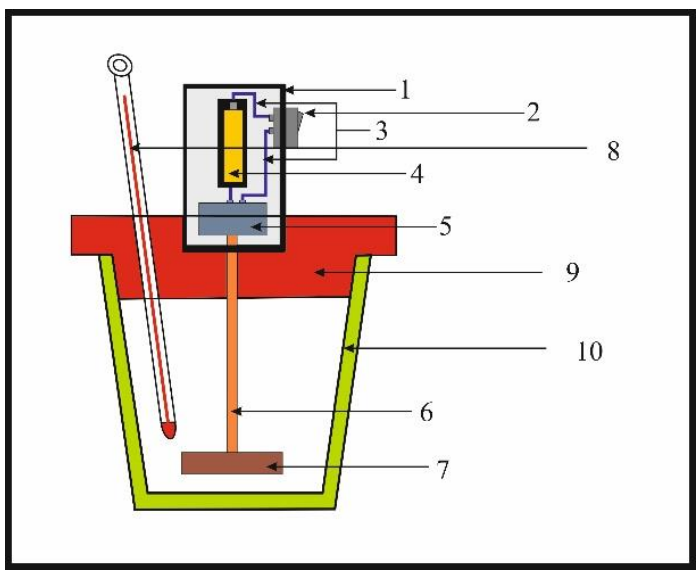

. Figure 2. The design of calorimeter

Caption:

1 = black box

2 = Switch

3 = Copper wire

$4=$ Thermometer

5 = Dynamo

$6=$ Cover

7 = Container

$8=$ Stirring rod

$9=$ pinwheel of stirring

The size of the container obtained varies according to the availability of material, because it comes from waste material that can still be used again. The calorimeter container size specifications can be seen in Table 2.

Table 2. The size of the calorimeter container from waste

\begin{tabular}{cccc}
\hline Material & Diameter & Thickness & Height \\
\hline Styrofoam & $95 \mathrm{~mm}$ & $2,8 \mathrm{~mm}$ & $68 \mathrm{~mm}$ \\
Paper & $77 \mathrm{~mm}$ & $2,2 \mathrm{~mm}$ & $80 \mathrm{~mm}$ \\
Plastic & $80 \mathrm{~mm}$ & $2 \mathrm{~mm}$ & $70 \mathrm{~mm}$ \\
Melamin & $70 \mathrm{~mm}$ & $2,2 \mathrm{~mm}$ & $75 \mathrm{~mm}$ \\
PVC & $97 \mathrm{~mm}$ & $3,2 \mathrm{~mm}$ & $82 \mathrm{~mm}$ \\
Bamboo & $69 \mathrm{~mm}$ & $6 \mathrm{~mm}$ & $9,8 \mathrm{~mm}$ \\
\hline
\end{tabular}

An automatic stirrer is composed of batteries, copper wire and dynamos. The circuit is placed on the black box which is connected with the stirring rod. Automatic stirrer can be seen in Figure 3.

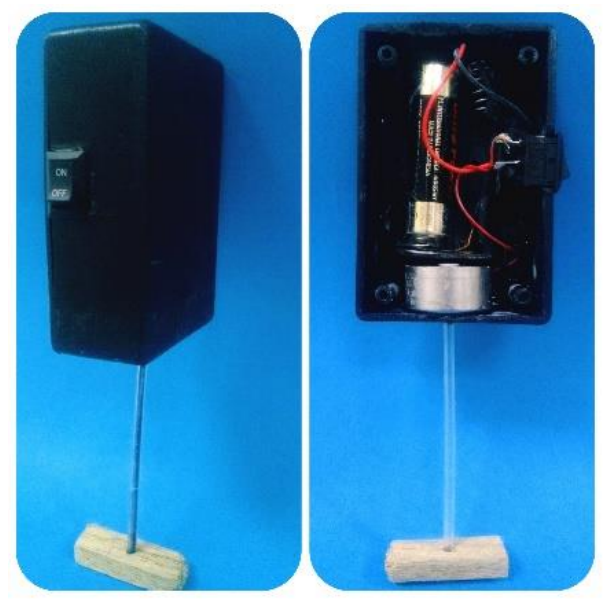

Figure 3. Automatic Stirrer

Stirrer rod material using waste plastic from the contents of the pen. Pinwheel of stirring using scrap wood. One of the calorimeter products made from bamboo can be seen in Figure 4.

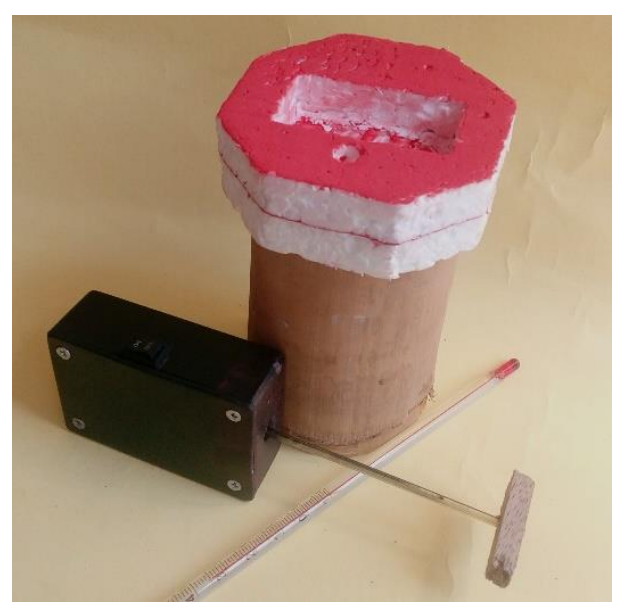

Figure 4. Calorimeter products made from bamboo

At the top of the container is closed with a styrofoam with a hole. The hole in the lid is used to place the automatic mixer and thermometer. 
The next step is to determine the most optimal container material used for the measurement of heat. This is done by determining the heat capacity and enthalpy of the neutralization reaction. Determination of heat capacity of the calorimeter aims to determine the absorption of the calorimeter to heat. The calorimeter's heat capacity (Ccal) is the amount of heat absorbed to increase the temperature of the calorimeter by $1^{\circ} \mathrm{C}$. [26].

Determination of heat capacity is done by mixing cold water and hot water. Initial and final temperatures are measured until a constant mixture temperature data is obtained. The data obtained is used to calculate the calorimeter heat capacity value. [27].

The procedure for determining the calorimeter's heat capacity is as follows: A total of $50 \mathrm{~mL}$ of cold water is put into the calorimeter and the calorimeter is closed. The automatic stirrer is turned on by pressing the switch. Water temperature is measured and recorded every minute up to five times the temperature reading. Then the automatic stirrer is turned off. As much as $50 \mathrm{~mL}$ of water (temperature $\pm 50^{\circ} \mathrm{C}$ ) is put into a calorimeter that has been filled with cold water. The calorimeter is closed and the automatic stirrer is turned on. The temperature of the mixed water is measured and recorded every one minute. Temperature measurements are carried out in order to obtain a constant temperature. In the experiment, the temperature of cold water and hot water were $28.5^{\circ} \mathrm{C}$ and $54^{\circ} \mathrm{C}$ respectively. The results of determining the calorimeter heat capacity can be seen in Table 3.

Based on Table 3 , PVC pipe material has the largest Ccal value of $309,519 \mathrm{~J} /{ }^{\circ} \mathrm{C}$. Styrofoam has the lowest Ccal value of $81,881 \mathrm{~J} /{ }^{\circ} \mathrm{C}$. This $\mathrm{Ccal}$ value data is used to calculate the value of neutralization enthalpy change. Observation results when cold water is put into the calorimeter shows the calorimeter material does not absorb heat from cold water. This was proven by observations of temperature that did not change up to five times reading. Temperature changes occur after cold water is mixed with hot water. Recording temperature changes to a constant to ensure precise temperature change. The difference in temperature changes is used as data for calculating the heat capacity and heat of the reaction (change in reaction enthalpy) [28].

\begin{tabular}{cccccccc}
\hline \multicolumn{7}{c}{ Table 3. The results of determining the calorimeter heat capacity } \\
\hline \multicolumn{2}{c}{ Material } & Styrofoam & Paper & Plastic & Melamin & PVC pipe & Bamboo \\
\hline \multirow{2}{*}{ Ccal } & Experiment 1 & 66,500 & 114,950 & 209,000 & 292,600 & 292,600 & 292,600 \\
$\left(\mathrm{~J} /{ }^{\circ} \mathrm{C}\right)$ & Experiment 2 & 89,571 & 114,950 & 209,000 & 248,188 & 343,357 & 292,600 \\
& Experiment 3 & 89,571 & 143,000 & 209,000 & 248,188 & 292,600 & 248,188 \\
& Average & 81,881 & 124,300 & 209,000 & 262,992 & 309,519 & 277,796 \\
\hline
\end{tabular}

Mixed water temperature data for each calorimeter from various simple materials is different. This shows that each calorimeter has a different heating capacity value, because the thermal conductivity of each calorimeter container material is different. The order of thermal conductivity values starting from the smallest in a row is Styrofoam $(0,08$ 
$\mathrm{W} / \mathrm{mK})$, plastic $(0,27 \mathrm{~W} / \mathrm{mK}), \mathrm{PVC}$ pipe $(0,28$ $\mathrm{W} / \mathrm{mK})$, melamine $(0,40 \mathrm{~W} / \mathrm{mK})$, paper $(3,45$ $\mathrm{W} / \mathrm{mK})$, and bamboo $(7,529 \mathrm{~W} / \mathrm{mK})$. [22], [29].

The Styrofoam calorimeter has the smallest Ccal value, while the PVC pipe calorimeter has the largest Ccal value. This shows that Styrofoam calorimeters have a better ability to withstand heat transfer from the system to the environment or vice versa [30]. Based on the value of thermal conductivity [22], the Ckal of a bamboo calorimeter should be greater the PVC pipe, because the thermal conductivity value is also greater. However, it is suspected that the size and thickness affect the Ccal value. PVC pipe calorimeters are relatively thinner than bamboo calorimeters [31].
Determination of the enthalpy change of neutralization is done with the following procedure: Prepare a solution of acid and alkaline solutions which have a number of moles and the same volume. The acid and base solutions used were $50 \mathrm{~mL}$ of $1 \mathrm{M} \mathrm{HCl}$ solution and $1 \mathrm{M} \mathrm{NaOH}$ solution, respectively. The temperature of $1 \mathrm{M} \mathrm{HCl}$ solution and $1 \mathrm{M}$ $\mathrm{NaOH}$ solution were measured to determine the initial temperature. Then prepare the calorimeter that has been determined the value of the heat capacity. Then $50 \mathrm{~mL}$ of $1 \mathrm{M}$ $\mathrm{HCl}$ is poured into the calorimeter. The calorimeter is closed and the stirrer is turned on. The temperature of the solution in the calorimeter is measured and recorded every minute for up to five times the temperature reading.

\begin{tabular}{|c|c|c|c|c|c|c|c|}
\hline \multicolumn{2}{|c|}{ Calorimeter material } & Styrofoam & Paper & Plastic & Melamin & PVC pipe & Bamboo \\
\hline \multirow{4}{*}{$\underset{(\mathrm{kJ} / \mathrm{mol})}{\Delta \mathrm{H}^{\circ} \mathrm{n}}$} & Experiment 1 & $-43,605$ & $-45,834$ & $-50,160$ & $-52,584$ & $-49,742$ & $-52,584$ \\
\hline & Experiment 2 & $-45,681$ & $-47,966$ & $-53,922$ & $-49,298$ & $-53,295$ & $-56,848$ \\
\hline & Experiment 3 & $-40,606$ & $-50,490$ & $-46,398$ & $-53,295$ & $-49,742$ & $-53,295$ \\
\hline & Average & $-43,297$ & $-48,096$ & $-50,160$ & $-51,726$ & $-50,926$ & $-54,242$ \\
\hline
\end{tabular}

After that the switch is pressed to turn off the stirrer. Then $50 \mathrm{~mL}$ of $1 \mathrm{M} \mathrm{NaOH}$ solution was poured into the calorimeter. The calorimeter is closed. The switch is pressed to turn on the stirrer. The temperature of the mix solution is measured and recorded every minute for up to five times the temperature readingThe temperature of the mixed solution in the calorimeter is observed and recorded every one minute. Temperature recording is carried out until a constant temperature is obtained. After that the switch is pressed to turn off the stirrer. The results of initial temperature measurement of $\mathrm{HCl}$ and $\mathrm{NaOH}$ solutions are the same, which is $28.5^{\circ} \mathrm{C}$. The results of determining the change in neutralization enthalpy $\left(\Delta \mathrm{Hn}^{\circ}\right)$ can be seen in Table 4. Based on Table 4 , the greatest $\Delta \mathrm{Hn}{ }^{\circ}$ value is found in the bamboo calorimeter which is $-54,242 \mathrm{~kJ} / \mathrm{mol}$. While the smallest value of $\Delta \mathrm{Hn}{ }^{\circ}$ is found on a Styrofoam calorimeter that is $-43.297 \mathrm{~kJ} / \mathrm{mol}$. The result of $\Delta \mathrm{Hn}^{\circ}$ will be compared with the value of $\Delta \mathrm{Hn}^{\circ}$ theoretically so that the percentage of accuracy (\% accuracy) of the calorimeter can be determined. The value of $\Delta \mathrm{Hn}^{\circ}$ is theoretically determined by changing the enthalpy of formation data for each ion involved in the 
reaction [23]. The value of $\Delta \mathrm{Hn}^{\circ}$ reaction of $\mathrm{HCl}$ and $\mathrm{NaOH}$ can theoretically be seen in equation 3.

$$
\begin{aligned}
& \mathrm{HCl}(\mathrm{aq})+\mathrm{NaOH}(\mathrm{aq}) \rightarrow \mathrm{H}_{2} \mathrm{O}(\mathrm{l})+\mathrm{NaCl}(\mathrm{aq}) \\
& \Delta \mathrm{H}^{\circ} \mathrm{n}=-55,8 \mathrm{~kJ} / \mathrm{mol}
\end{aligned}
$$

Percent accuracy of determining $\Delta \mathrm{Hn}^{\circ}$ by using calorimeters from various simple materials can be seen in Table 5 .

Tabel 5. Optimization results in determining the value $\Delta \mathrm{Hn}{ }^{\circ}$

\begin{tabular}{clc}
\hline No & Calorimeter Material & $\%$ accuracy \\
\hline 1. & Styrofoam & 78 \\
2. & Paper & 86 \\
3. & Plastic & 90 \\
4. & Melamin & 93 \\
5. & PVC pipe & 91 \\
6. & Bamboo & 97 \\
\hline
\end{tabular}

Based on Table 5, the biggest accuration is in the bamboo calorimeter of $97 \%$. While the smallest accuracy $\%$ is found on Styrofoam calorimeters by $78 \%$. The $\Delta \mathrm{Hn}^{\circ}$ value measured using a bamboo calorimeter is closest to the theoretical $\Delta \mathrm{Hn}^{\circ}$ value.

The difference in the value of the change in neutralization enthalpy is due to the influence of the difference in the Ccal value on the calorimeter of various simple materials. Bamboo calorimeter produces the most optimal neutralization enthalpy change because it has a large Ccal value. Whereas the Styrofoam calorimeter produces the smallest neutralization enthalpy change in line with a small Ccal value. The heat absorbed by the Styrofoam calorimeter is small even though the temperature measurements in the neutralization reaction experience greater changes. The difference in thickness of the material used also affects the data produced [22], [32] .

Validation tests on the calorimeter from various waste materials were carried out by three validators. Validators are asked to test the product based on seven aspects, namely aspects of conformity with learning objectives, aspects of practicality, aspects of aesthetics and durability, aspects of equipment efficiency, safety aspects for students, environmental aspects, and aspects of clarity of instructions for use. During validation, the researcher shows and demonstrates the use of the product. The validator provides assessments and suggestions for improvement. The results of the assessment and suggestions for improvement are used to perfect the product, so it is ready for use for the next stage. The results of the validation test can be seen in Table 6.

Table 6. The results of validation test of product

\begin{tabular}{clc}
\hline No & \multicolumn{1}{c}{ Aspect } & $\begin{array}{c}\text { Result of } \\
\text { validation }\end{array}$ \\
\hline 1 & conformity with learning & 0,81 \\
2 & objectives & 0,83 \\
3 & Practicallity & 0,75 \\
4 & Epearance and durability & 0,81 \\
5 & Security & 0,75 \\
6 & Environment & 0,75 \\
7 & Clarity of use instructions & 0,73 \\
& Average & 0,78 \\
\hline
\end{tabular}

Based on Table 6, it can be seen that the highest value is found in the practical aspect with a calculated value of 0.83 . While the lowest value is in the aspect of clarity of use instructions with a calculated value of 0.73 . The average value of the count from all aspects is 0.78 . From the results of validation on all aspects it can be concluded that calorimeters from various simple materials 
are declared valid and ready to be tested. The input provided by the validator is the product is designed to have the same size and beautify the appearance of the product.

The feasibility test was carried out by conducting a limited test of 12 students who were divided into six groups. The student has attended and passed an energetics course. In this feasibility test, students assess calorimeter products from various simple materials with six aspects, namely aspects of practicality, aspects of aesthetics and durability, aspects of equipment efficiency, safety aspects for students, environmental aspects, and aspects of clarity of instructions for use. The results of the Feasibility Test can be seen in Table 7.

Table 7. The results of feasibility test of product

\begin{tabular}{|c|c|c|c|}
\hline No & Aspect & $\begin{array}{l}\text { feasibility } \\
\text { results } \\
(\%)\end{array}$ & Interpretation \\
\hline 1 & Practicallity & 97,22 & Very feasible \\
\hline 2 & $\begin{array}{l}\text { Apearance } \\
\text { and durability }\end{array}$ & 87,50 & feasible \\
\hline 3 & Efficiency & 97,22 & Very feasible \\
\hline 4 & Security & 100 & Very feasible \\
\hline 5 & Environment & 93,75 & Very feasible \\
\hline \multirow[t]{2}{*}{6} & $\begin{array}{l}\text { Clarity of use } \\
\text { instructions }\end{array}$ & 93,23 & Very feasible \\
\hline & Average & 94,49 & Very feasible \\
\hline
\end{tabular}

Based on Table 7, the overall rating is categorized as very feasible to use (average percentage of $94.49 \%$ ). Based on that, calorimeters from various simple materials are ready to be used as learning media.

In the aspect of conformity with learning material, the validation results obtained a rcount value of 0.81 which shows calorimeters from various simple materials in accordance with the national curriculum, so that it can be used in chemistry learning of thermochemical material, especially in practicum activities [11]. This is in accordance with that stated that the teaching aids that are made must be in accordance with the subject matter so as to make it easier for students to understand the subject matter [33].

In the practical aspect, the validation results have a calculated value of 0.83 and the feasibility results have a percentage of $97.22 \%$ indicating that calorimeters from various simple materials are practically used. Simple laboratory standard calorimeters are still used manually so stirring the solution in the calorimeter is not constant. In addition, the tip of the ring-shaped stirring rod makes the calorimeter stirring less evenly distributed. Therefore modifications were made to the calorimeter design of a variety of simple materials, which is equipped with an automatic stirring design as shown in Figure 1 so that a simple calorimeter design was formed as a result of the modification as shown in Figure 2 .

The existence of an automatic stirrer is characteristic of calorimeter products from a variety of simple materials because the existence of an automatic stirrer makes a calorimeter from a variety of simple materials easy to use. In addition, calorimeters from a variety of simple materials are easily treated properly because the components are easily removable. This is in line with the fact that using technology makes things easier [34] .

In the aspect of display and durability of the tool, the results of the validation have a calculated value of 0.75 and are supported by the feasibility results with a percentage of $87.50 \%$ so that it shows that calorimeters from various simple materials have a good appearance and durability so as to attract 
students' interest in the products used and the product can be used for a long time.

The making of calorimeter from various simple materials is adjusted to the calorimeter design that has been made as shown in Figure 2 so as to create a product that has a good appearance. Appearance becomes the main thing as a support for a work that can be enjoyed [35]. In addition to the props that have a good display can increase the attractiveness of students so that students do not get bored when using props [21].

By using various simple materials obtained from used goods in the manufacture of calorimeters from various simple materials, the product has good durability. Simple material used as a calorimeter vessel using material that does not leak easily. In addition, the components of an automatic stirrer which are protected by a black box make the calorimeter from various simple materials not easily damaged. This is in accordance with that stated that props must have a good tool durability intended so that props are not easily damaged and can be used in a relatively long time [35].

In the aspect of tool efficiency, the results of the tool validation have a calculated value of 0.81 and the feasibility results which obtained a percentage of $97.22 \%$ indicate that a simple calorimeter is made efficiently. Simple calorimeters available in laboratories are relatively expensive. To overcome this, a simple calorimeter can be made using a variety of simple materials that have a price that is everyday life so as to produce an efficient product. This is in accordance with the stated that props can be created at a cost that is affordable and easily obtained [32].
In the aspect of tool safety, the validation results have a calculated value of 0.75 and are supported by the feasibility results with a percentage of $100 \%$ so that it shows that calorimeters from various simple materials are safe to use and simple materials used are not dangerous [33].

The calorimeter components of various simple materials are designed with safety considerations for students by using tools and materials that are non-toxic and harmless to humans as well as the environment in accordance with the green chemistry approach. Green chemistry studies include concepts and effective approaches to anticipate environmental pollution [24], [36].

\section{CONCLUSION}

The results of calorimeter optimization from various simple materials (styrofoam, paper, plastic, melamine, PVC and bamboo pipes) in determining the calorimeter heat capacity and the change in neutralization enthalpy obtained the calorimeter accuracy value between $78-97 \%$. The highest accuracy is obtained by bamboo calorimeter and the lowest accuracy is obtained by styrofoam calorimeter. The validation test results of 0.78 and the feasibility test results of $94.49 \%$ indicate that calorimeters from various simple materials are feasible and ready to be used as learning media.

\section{REFERENCES}

[1] Sari \& R. Hidayat, "Pengembangan Keterampilan Berpikir Kreatif Siswa Pada Prraktikum Jenis-Jenis Koloid: Pendekatan Saintifik," J. Tadris Kim., vol. 1, no. 1, pp. 32-37, 2017. DOI:10.15575/jta.v1i1.1155 
[2] N. A. Safitri, S. Rahmatullah, Y. Dirgantara, \& I. Farida, "Using CaseBased Reasoning To Solve Water Purification Problems," Adv. Soc. Sci. Educ. Humanit. Res., vol. 261, no. Agst, pp. 107-110, 2018.

DOI:10.2991/icie-18.2018.19

[3] S. Sari, S. A. Ferawati, I. Farida, O. Sobandi, and R. Kariadinata, "Online based performance assessment for general chemistry laboratory," in IOP Conference Series: Materials Science and Engineering, vol. 434, no. 1, p. 12190, 2018

DOI:10.1088/1757-899x/434/1/012190

[4] Y. Prasetyo, R. Yektyastuti, J. Ikhsan, K. Sugiyarto, \& M. Sholihah, "Pengaruh Penggunaan Media Pembelajaran Kimia Berbasis Android Terhadap Peningkatan Motivasi Belajar Siswa," Pros. Semin. Nas. Pendidik. Sains, 2015.

[5] J. R. Horn, D. Russell, E. A. Lewis, \& K. P. Murphy, "van't Hoff and Calorimetric Enthalpies from Isothermal Titration Calorimetry: Are There Significant Discrepancies?," Biochemistry, vol. 40, no. 6, pp. 1774-1778, Feb. 2001. DOI: $10.1021 / \mathrm{bi002408e}$

[6] T. Nilsson \& H. Niedderer, "Undergraduate students' conceptions of enthalpy, enthalpy change and related concepts," Chem. Educ. Res. Pract., vol. 15, no. 3, pp. 336-353, 2014. DOI:10.1039/C2RP20135F

[7] E. Kavanagh, S. Mindel, G. Robertson, \& D. E. P. Hughes, "An inexpensive solution calorimeter," J. Chem. Educ., vol. 85, no. 8, pp. 1129-1130, 2008. DOI:10.1021/ed085p1129

[8] M. W. Vannatta, M. Richards-Babb, and R. J. Sweeney, "Thermochemistry to the Rescue: A Novel Calorimetry Experiment for General Chemistry," J. Chem. Educ., vol. 87, no. 11, pp. 1222-1224, Nov. 2010.

DOI:10.1021/ed100036y

[9] R. A. Bailey, "A solution calorimeter and thermistor bridge for undergraduate laboratories" J. Chem. Educ., vol. 58, no.9, pp732,1981.

DOI:10.1021/ed058p732
[10] K. V. Mills \& L. W. Guilmette, "Thermochemical analysis of neutralization reactions: An introductory discovery experiment," J. Chem. Educ., vol. 84, no. 2, pp. 326-328, 2007. DOI:10.1021/ed084p326

[11] T. Tatsuoka, K. Shigedomi, \& N. Koga, "Using a Laboratory Inquiry with High School Students to Determine the Reaction Stoichiometry of Neutralization by a Thermochemical Approach," J. Chem. Educ., vol. 92, no. 9, pp. 15261530, 2015.

DOI:10.1021/ed500947t

[12] A. M. R. P. Bopegedera and K. N. R. Perera, "'Greening' a Familiar General Chemistry Experiment: Coffee Cup Calorimetry to Determine the Enthalpy of Neutralization of an Acid-Base Reaction and the Specific Heat Capacity of Metals," J. Chem. Educ., vol. 94, no. 4, pp. 494-499, 2016.

DOI:10.1021/acs.jchemed.6b00189

[13] J. J. Stankus \& J. D. Caraway, "Replacement of coffee cup calorimeters with fabricated beaker calorimeters," J. Chem. Educ., vol. 88, no. 12, pp. 1730-1731, 2011.

DOI:10.1021/ed100145u

[14] Marnita, "Peningkatan Kemampuan Berpikir Kritis Siswa MTsN Melalui Pembelajaran Berbasis Masalah Berbantuan Alat Peraga Pompa Hidrolik Sederhana Konsep Tekanan," J. Pendidik. Almuslim, vol. 4, no. 1, pp. 22-33, 2016.

[15] I. Farida, I. Helsy, \& M. Nurmelati, "Pengembangan Prototype Reaktor Dan Prosedur Eksperimen Pembuatan Biogas Skala Rumah Tangga Dari Sampah Organik Untuk Pembelajaran Kimia," in Seminar Nasional Sains dan Teknologi, 2015.

[16] T. Anderson \& J. Shattuck, "DesignBased Researh : A Decade of Progress in Education Research?," Educ. Res., vol. 41, no. 1, pp. 16-25, 2012. DOI:10.3102/0013189X11428813

[17] A. K. N. Hess \& K. Greer, "Designing for Engagement: Using the ADDIE Model to Integrate High-Impact Practices into an Online Information 
Literacy Course," Commun. Inf. Lit., vol. 10, no. 2, pp. 264-282, 2016.

DOI:10.15760/comminfolit.2016.10.2.27

[18] Sugiyono, "Metode Penelitian dan Pengembangan," 2nd ed., Bandung: Alfabeta, 2015, pp. 164-172.

[19] Y. Munadi, "Media Pembelajaran," Media Pembelajaran, Jakarta: Gaung persada press pp. 7-8, 2013.

[20] Y. Munadi, Media pembelajaran sebuah pendekatan, Keempat. Jakarta: Gaung Persada (GP) Press, 2008.

[21] D. Mayangsari, F. S. Irwansyah, \& I. Farida, "The making of metal coating props oriented chemical representation," in Journal of Physics: Conference Series, vol. 1402, no. 5, p. 55034, 2019.

DOI:10.1088/1742-6596/1402/5/055034

[22] F. Burlian \& M. I. Khoirullah, "Pengaruh Variasi Ketebalan Isolator Terhadap Laju Kalor dan Penurunan Temperatur pada Permukaan Dinding Tungku Biomassa," Semin. Nas. Mesin dan Ind., pp. 208-214, 2014.

[23] B. J. Knurr \& J. F. Hauri, "An Alternative to Recycling: Measurement of Combustion Enthalpies of Plastics via Bomb Calorimetry," J. Chem. Educ., Apr. 2020.

DOI:10.1021/acs.jchemed.0c00076

[24] M. Paristiowati, Z. Zulmanelis, \& M. F. Nurhadi, "Green Chemistry-Based Experiments As the Implementation of Sustainable Development Values," J. Tadris Kim., vol. 4, no. 1, pp. 11-20, 2019.

DOI:10.15575/jtk.v4i1.3566

[25] C. E. Bennett, W. Virginia, \& R. J. Sweeney, "Calorimetry Experiment for General Chemistry," J. Chem. Educ., vol. 87, no. 11, pp. 10-12, 2010. DOI:10.1021/ed100036y

[26] R. Chang, Kimia Dasar KonsepKonsep Inti, 3rd ed. Jakarta: Penerbit Erlangga, 2005.
[27] R. E. Barlag, P. Arthasery, \& F. Nyasulu, "Electrical determination of the heat capacity of a calorimeter in approximately one minute," J. Chem. Educ., vol. 87, no. 9, p. 992, 2010. DOI:10.1021/ed100318u

[28] M. S. Silberberg, Principles of General Chemistry, 3rd ed. New York: Mc Graw Hill, 2013.

[29] E. B. Ettah, J. G. Egbe, S. A. Takim, U. P. Akpan, \& E. B. Oyom, "Investigation of the Thermal Conductivity of Polyvinyl Chloride (Pvc) Ceiling Material Produced In Epz Calabar, For Application Tropical Climate Zones," J. Polym. Text. Eng., vol. 3, no. 2, pp. 34-38, 2016.

[30] Y. Kuang, G. Chen, \& Z. Fang, "A Facile Approach to Evaluate Thermal Insulation Performance of Paper Cups," Int. J. Polym. Sci., vol. 2015, p. 367962, 2015.

DOI:10.1155/2015/367962

[31] N. Z. Jusoh, A. M. Zakaria, M. Ahmad, \& A. Ibrahim, "Thermal conductivity of Akar blamboo (Dendracalamus pendulus) and Semantan bamboo (Gigantochloa scortechinii)," Adv. Mater. Res., vol. 748, pp. 160-164, 2013.

[32] J. J. Stankus \& J. D. Caraway, "Replacement of coffee cup calorimeters with fabricated beaker calorimeters," J. Chem. Educ., vol. 88, no. 12, pp. 17301731, 2011.

DOI:10.4028/www.scientific.net/AMR.748.160

[33] D. T. Miles \& A. C. Borchardt, "Laboratory Development and Lecture Renovation for a Science of Food and Cooking Course," J. Chem. Educ., vol. 91, no. 10, pp. 1637-1642, Oct. 2014.

DOI:10.1021/ed5003256

[34] I. Farida, R. R. Zahra, and F. S. Irwansyah, "Experiment Optimization On The Reaction Rate Determination And Its Implementation In Chemistry Learning To Develop Science Process Skills," J. Pendidik. Sains Indones. (Indonesian J. Sci. Educ., vol. 8, no. 1, pp. 67-77, 2020.

DOI:10.24815/jpsi.v8i1.15608 
[35] I. Farida, R. Kheiriah, S. Sari, \& F. S. Irwansyah, "Application of the principle of hydraulic cranes on the conductivity tester," in Journal of Physics: Conference Series, 2019, vol. 1402, no. 5 , p. 55072.

DOI:10.1088/1742-6596/1402/5/055072
[36] T. Lindstrom \& C. Middlecamp, "Campus as a Living Laboratory for Sustainability: The Chemistry Connection," J. Chem. Educ., vol. 94, no. 8, pp. 1036-1042, Aug. 2017.

DOI:10.1021/acs.jchemed.6b00624 